DR CAROLINA MONTERO-LOPEZ (Orcid ID : 0000-0002-3943-5648)

Article type : Original Article

\title{
DEVELOPMENT OF AN INCIPIENT PALEOGENE TOPOGRAPHY BETWEeN THE PRESENT-DAY Eastern ANdean Plateau (Puna) ANd the Eastern Cordillera, SOUTHERn CENTRAL ANDES, NW ARGENTINA
}

\section{Running title: PALEOGENE DEFORMATION IN NW ARGENTINA}

Carolina Montero-López ${ }^{\mathrm{a}^{*}}$

Fernando Hongna,

Romina L. López Steinmetz ${ }^{b}$

Alejandro Aramayo ${ }^{\mathrm{a}}$

Heiko Pingel ${ }^{\mathrm{c}}$

Manfred R. Strecker ${ }^{\mathrm{c}}$

John M. Cottled

Carlos Bianchi ${ }^{\mathrm{a}}$

This article has been accepted for publication and undergone full peer review but has not been through the copyediting, typesetting, pagination and proofreading process, which may lead to differences between this version and the Version of Record. Please cite this article as doi: 10.1111/BRE. 12510

This article is protected by copyright. All rights reserved 
anstituto de Bio y Geociencias del NOA (IBIGEO), Universidad Nacional de Salta-CONICET, 9 de Julio 14, 4405 Rosario de Lerma, Salta, Argentina. cmontero@conicet.gov.ar, fhongn@conicet.gov.ar, alejandrojaramayo@yahoo.com.ar, bianchicarlosluis76@gmail.com

bInstituto de Eco Regiones Andinas (INECOA), Universidad Nacional de Jujuy-CONICET, Av. Bolivia 1661, 4600 S.S. de Jujuy, Jujuy, Argentina. lucrecialopezsteinmetz@hotmail.com

cInstitut für Geowissenschaften, Universität Potsdam, Karl-Liebknecht Str. 24-25, 14476 Potsdam, Germany. strecker@geo.uni-potsdam.de, heikop@geo.uni-potsdam.de

dDepartment of Earth Science and Earth Research Institute, University of California, Santa Barbara, CA93106, USA.cottle@geol.ucsb.edu

*Corresponding author: cmontero@conicet.gov.ar

\section{Acknowledgments}

The authors acknowledge financial support by FONCyT-ANPCyT (PICT-0432, PICT-1928) and CONICET (PUE-IBIGEO) from Argentina. Additional support came from DFG grant STR 373/34-1 and the Brandenburg Ministry of Sciences, Research and Cultural Affairs, Germany, within the framework of the international IGK2018 research training group "SuRfAce processes, TEctonics and Georesources: The Andean foreland basin of Argentina (StRATEGy)". We are grateful to Humberto Tolaba and his family (Laguna Colorada area, Jujuy province) for their hospitality and to A. Scanferla and R.N. Alonso for constructive discussions. We thank T. Jordan, A. Stevens Goddard and D. Pearson for helpful comments that improved the manuscript and N. McQuarrie for editorial handling.

\section{Data availability statement}

The data that support the findings of this study are provided in the Supplementary Material.

There is no conflict of interest concerning to this contribution.

This article is protected by copyright. All rights reserved 


\section{Abstract}

The structural and topographic evolution of orogenic plateaus is an important research topic because of its impact on atmospheric circulation patterns, the amount and distribution of rainfall, and resulting changes in surface processes. The Puna region in the north-western Argentina (between $13^{\circ} \mathrm{S}$ and $27^{\circ} \mathrm{S}$ ) is part of the Andean Plateau, which is the world's second largest orogenic plateau. In order to investigate the deformational events responsible for the initial growth of this part of the Andean plateau, we carried out structural and stratigraphic investigations within the present-day transition zone between the northern Puna and the adjacent Eastern Cordillera to the east. This transition zone is characterized by ubiquitous exposures of continental middle Eocene redbeds of the Casa Grande Formation. Our structural mapping, together with a sedimentological analysis of these units and their relationships with the adjacent mountain ranges, has revealed growth structures and unconformities that are indicative of syntectonic deposition. These findings support the notion that tectonic shortening in this part of the Central Andes was already active during the middle Paleogene, and that early Cenozoic deformation in the region that now constitutes the Puna occurred in a spatially irregular manner. The patterns of Paleogene deformation and uplift along the eastern margin of the present-day plateau correspond to an approximately north-south oriented swath of reactivated basement heterogeneities (i.e. zones of mechanical weakness) stemming from regional Paleozoic mountain building that may have led to local concentration of deformation belts.

Keywords: Eocene deformation; southern Central Andes; Andean Plateau; northern Puna; Eastern Cordillera; growth structures; north-western Argentina

\section{Introduction}

The southern Central Andes in north-western Argentina and southern Bolivia are an integral part of the largest Cenozoic non-collisional mountain belt on Earth. Its structural and topographic evolution has been the subject of controversial discussion over the last 25 years, resulting in a number of different models for the uplift of the Andean Plateau and adjacent morphotectonic provinces (Jordan et al., 1983; Allmendinger et al., 1997; Oncken et al., 2006; Garzione et al., 2017). In this study, we address some of the issues concerning the spatiotemporal evolution of deformation in north-

This article is protected by copyright. All rights reserved 
western Argentina and focus on tectono-sedimentary patterns exposed within the transition zone between the present-day Andean Plateau and the Eastern Cordillera, in order to assess two possible scenarios, one (a) involving systematic eastward-directed plateau growth, and the second (b) involving more diachronous and spatially irregular patterns of uplift and sedimentation for the mountain ranges and basins that compass the present-day plateau region.

The Andean Plateau (between latitudes $13^{\circ} \mathrm{S}$ and $27^{\circ} \mathrm{S}$; Isacks, 1988) is a largely internally drained region in the interior of the Andean orogen (Fig. 1a), with an average elevation between 3.5 $4 \mathrm{~km}$ asl, which is bordered by the Eastern and Western cordilleras (Fig. 1a). The Argentine sector of the plateau in particular (Fig. 1b), i.e. the Puna (Turner, 1972), is characterized by numerous basins, some of which are isolated, with intervening reverse-fault-bounded mountain ranges and volcanic edifices that reach elevations of 5 to $7 \mathrm{~km}$ asl (Turner, 1972; Isacks, 1988; Allmendinger et al., 1997). A set of related research questions currently under discussion is whether the present-day elevation of this sector of the Andes was achieved during the Paleogene (e.g. Canavan et al., 2014; Quade et al., 2015), as a result of large-scale surface uplift much later during the Neogene (e.g. Garzione et al., 2008; Ghosh et al., 2006), or a result of episodic growth (e.g. Reiners et al., 2015; Pingel et al., 2020). Other discussions have focused on whether early Cenozoic mountain building was characterized by an eastward-directed younging of deformation (DeCelles et al., 2011; Carrapa \& DeCelles, 2015; Reiners et al., 2015), or whether deformation and uplift were spatially distributed across the entire region that now constitutes the Andean Plateau and Eastern Cordillera during the Paleogene (e.g. Hongn et al., 2007; del Papa et al., 2013; Aramayo et al., 2017).

Previous investigations have demonstrated the existence of two Eocene-Oligocene deformation belts coinciding with the present-day Western and Eastern cordilleras that border the proto-Altiplano in Bolivia, and that deformation propagated from these belts toward the interior of the Altiplano (Lamb \& Hoke, 1997; Elger et al., 2005; Oncken et al., 2006; Ege et al., 2007). For our investigations we focused on the region of the southern continuation of the eastern Bolivian deformation belt into north-western Argentina. Compared to the well-documented Paleogene deformation in the Altiplano, the isolated outcrops of syntectonic sedimentation along the western and eastern borders of the Puna have yielded relatively little information about the early history along its margins (Mpodozis et al., 
2005; Hongn et al., 2007; del Papa et al., 2013), and within the interior of the Puna (Kraemer et al., 1999; Jordan \& Mpodozis, 2006; Carrapa et al., 2005; Carrapa \& DeCelles, 2008). Despite the limited data available, a number of hypotheses have been proposed for the structural and topographic evolution of the area during the Paleogene. Canavan et al. (2014) and Quade et al. (2015), for example, suggested on the basis of stable isotope palaeoaltimetry that a plateau of about $4 \mathrm{~km}$ asl elevation already existed during the late Eocene. Other authors have, in contrast, suggested the existence of a broad, low-elevation plain in the region of the present-day Puna during the Paleogene that was interrupted by uplifts of isolated mountain ranges with generally subdued topography (e.g. Adelmann, 2001; Carrapa et al., 2005; DeCelles et al., 2007; Pingel et al., 2019, 2020).

Some of the best evidence for the first manifestations of crustal shortening during EoceneOligocene times has been preserved in the transition zone between the Puna and the Eastern Cordillera, south of $24.5^{\circ} \mathrm{S}$ (e.g. Hongn et al., 2007; Payrola Bosio et al., 2009). This evidence comprises syntectonic sedimentation features such as growth strata, progressive unconformities, and intraformational unconformities, located along structures that delimit irregularly distributed basins with internal drainage (e.g. del Papa et al., 2013). There is, however, a gap in the records of Paleogene deformation and associated sedimentation in the transition zone between the Puna and the Eastern Cordillera, between $22^{\circ} \mathrm{S}$ and $24.5^{\circ} \mathrm{S}$ (Figs. $1 \mathrm{~b}$ and 1c), with most of the evidence of EoceneOligocene tectonism coming from areas within the Puna (Montero-López et al., 2018 and references therein).

In this study we highlight the importance of the southern continuation into the Eastern Cordillera of NW Argentina of the Paleozoic eastern Bolivian deformation belt in controlling regional Cenozoic deformation in the transition zone between the Puna and the Eastern Cordillera. This region of transition zone corresponds to the Sierra Alta mountain range (between approximately $23^{\circ} \mathrm{S}$ and $24^{\circ} \mathrm{S}$ ), which marks the present-day morphological border between the Puna and the Eastern Cordillera (Figs. 1b and 1c). Inherited Paleozoic structures and Cretaceous normal faults in the Sierra Alta (Rodríguez-Fernández et al., 1998; Monaldi et al., 2008) were reactivated during the Cenozoic Andean orogeny (e.g. Kley et al., 2005; Barrabino et al., 2017), as can also be commonly observed at many other locations in north-western Argentina.

This article is protected by copyright. All rights reserved 